\title{
Determinants of on-the-job Search Behavior: An Empirical Analysis
}

\author{
Tamás Bakó \\ Institute of Economics, Centre for Economics and Regional Studies, Hungarian Academy of Sciences, Budapest, Hungary \\ Faculty of Economics, University of Pannonia, Veszprém, Hungary \\ *Corresponding Author: bako.tamas@krtk.mta.hu
}

Copyright (C) 2015 Horizon Research Publishing All rights reserved.

\begin{abstract}
The primary aim of this paper was to shed light on the impact of subjective alternative wage, wage changes and wage discrimination on job search behavior of employees. The research was based on primary data; the survey was conducted among Hungarian internet user employees. Our results suggest that regardless of their job search behavior employees are aware of alternative wages, which have the greatest impact on intentions to quit and active search. With respect to wage cut and wage increase we have found that they are both significant; the former has strong positive effect on intentions to quit and active search, while the latter reduces the probability of on-the-job search. To our best knowledge, this study was the first to reveal direct impact of wage discrimination on job search behavior of employees according to which there is a weak, but positive effect on intentions to quit and active search. Last but not least, the results of our study confirm the role of non-financial incentives in job search, where superior-subordinate relationships have a special importance.
\end{abstract}

Keywords On-the-job Search, Alternative Wages, Wage Discrimination, Wage Cuts, Superior-subordinate Relationships

\section{Introduction}

Job mobility plays an essential role in the correction of imperfect job match; it is a mechanism that can foster the optimal allocation of human resources. At the same time, on-the-job search of employees and the resulting turnover represent significant cost to firms. Costs arise from the recruitment and training of new employees, on the one hand, and sunk costs of trained employees on the other, if the cost of training has only been partly paid back until the moment of quitting. Hence, the reduction of turnover is an important task of the corporate management, which, however, requires an in-depth knowledge of factors influencing intentions to quit. The most important projection of job search theory models (Burdett [19], Jesper at al. [7]) is that the higher the employer's wage, the lower the potential gain derived from job search, which, therefore, reduces the tendency to look for another job. Based on establishment level wages Martin [9] found a significant negative relationship between wages and turnover; that is, the higher the establishment wage, the lower the turnover. Ponzo [22] and Fuentes [2], among others, came to a similar conclusion using Italian and British data respectively. Furthermore, numerous researchers have inserted alternative wage into the regression model along with the own wage. Based on the literature, one of the most important driving factors for on-the-job search is the difference between the own-wage and the alternative wage. Based on industry level wages, Shorey [18] found that quits are positively influenced by the form of the external wage distribution, represented by its mean and variance. Black [21] found that the coefficient is significantly positive for the difference between the own-wage and the wage predicted by individual and firm characteristics, which also proves that employees react to other potential wages; the higher the available wage the more likely the worker to look for other jobs. However, the shortcoming of the above-mentioned studies is that they predicted the individual behavior based on industry-level wages or estimated alternative wages; therefore, they only provide for an indirect evidence on its impact. Souza-Poza and Henneberger's [4] study, to our best knowledge, has so far been the only one, in which the authors conducted a survey to reveal employees' subjective opinion on their own-wages and its impact on the job search behavior. Researchers asked respondents whether they thought their own-wage was high or low, and found that high wage level had a significantly negative effect on employees' quitting intention. The question was; however, somewhat ambiguous, since it did not clearly determine the reference wage (compared to which their own-wage regarded as high or low): the wage of employees working in the same field in the same firm, the own reservation wage, or the alternative wage available elsewhere. One of the novelties of this study is that it takes the subjective opinion of employees on alternative wage into account when it comes to explaining on-the-job search. In connection, we have also examined whether only 
job seekers are aware of alternative wages, or whether the majority of employees have an idea of other available wages. In accordance with the above described, the first two research questions are as follows:

1. Do employees have an idea on potentially available wages only if they are looking for another job at the moment, or they do so even if they are not actively involved in the job search?

2. Does the alternative wage perceived by the employees have a significant effect on intentions to quit or active search?

Furthermore, an important factor of on-the-job search is the change in wage level, but there are quite few available empirical results on the subject. Bewley [31] conducted interviews with CEOs about the damaging effects of a potential wage cut; CEOs most frequently pointed at the deterioration of work moral and the reduction of productivity; moreover, they especially highlighted the voluntary quitting of employees. Cambell and Kamlani [8] asked compensation professionals to evaluate the importance of different reasons for the reluctance to make wage cuts in recessions and they gave the most weight to the potential loss of the most productive workers. Wage cut is rare as an event in the life of an employee, if occurs at all, as opposed to wage increase, which is substantially more frequent. Based on the data reported by the Bureau of Labor Statistics between 1957 and 1978, Akerlof at al. [13] found that in most years, the proportion of employees who suffered a wage cut never exceeded a maximum of 4 percent, while each year at least 87 percent of the employees did benefit from a wage increase. Clark, Georgellis and Sanfey [6] studied the effect of change in wage level over two periods on voluntary quitting, and found that if the change in wage level was lower - due to a smaller wage increase, or a greater wage cut - the probability for voluntary quitting increased. Nevertheless, the authors did not show the effects of wage cut and wage increase separately, even though it would be important to know whether they are both significant or not, as well as their effect on job search behavior. Hence, our third research question is the following:

\section{Does wage cut and a wage increase have a significant effect on intention to quit and active search?}

In addition to wage variables, the effect of job satisfaction on intentions to quit has been receiving more and more attention in recent years (Shields and Price [24]). Based on data retrieved from cross-national surveys Souza-Poza and Henneberger [4] found that job satisfaction has one of the strongest influence on intentions to quit. Using survey data of public sector employees in the Netherlands, Delfgaauw [16] shows that workers' satisfaction with various job domains not only affects whether but also where workers search for another job. The author argues that workers try to leave their current employer when they are uncomfortable with an organisation-specific job domain, like management, but when they are dissatisfied with a job domains which may have an industry-specific component, such as job duties, they want to leave their industry. Based on the European Community Household Panel (ECHP) data for Danish families, Kristensen and Westergard-Nielsen [25] found that inclusion of job satisfaction does improve the ability to predict actual quit behavior: low overall job satisfaction significantly increases the probability of quit. The authors ranked various job satisfaction domains according to their ability to predict quits and they found that satisfaction with type of work is the most important job characteristic while satisfaction with job security is insignificant. Clark [5] uses labour market spell data from the first seven waves of the British Household Panel Survey and one of his main result was that the comparison of the power of seven domain job satisfaction measures in quit equation yields a ranking of job characteristics: job security and pay are the most important, followed by use of initiative, the work itself, and hours of work. Interestingly, the relationship of supervisors was statistically significant, but did not have a strong impact on quits.

There is an extensive literature studying wage discrimination as well as its impact on job satisfaction (Pfeffer and Langton [17], Johnson and Lambrinos [32], Groshen [12]); and the results show that wage discrimination significantly decreases job satisfaction. According to a survey led among faculty members, Pfeffer and Langton [17] found that the higher the spread of wages across the faculty, the lower the job satisfaction and research performance of faculty members, and they are less likely to cooperate during researches. However, to our knowledge, there are no studies exploring a direct relationship between wage discrimination and on-the-job search behavior. Barth and Dale-Olsen [11] found that excess turnover of workers in the establishments is significantly more sensitive to the wage premium of men than to that of women, which implies a higher elasticity of labour supply facing each establishment for men than for women. The authors argue that this difference provides employers with an incentive to employ the policy of monopsonistic discrimination. The shortcoming of the study is that it only showed the possibility of wage discrimination; therefore, our fourth research question is the following:

\section{Does wage discrimination have a direct effect on intentions to quit and active search?}

Apart from wage related variables and job satisfaction, individual characteristics also significantly influence the probability of on-the-job search. The elderly are less likely to look for a job, which is partly due to the fact they have a greater difficulty in learning the skills required by new jobs, while at the new job they can only benefit from the higher wages for a shorter period of time (Black [21], Fuentes [2]). On the other hand they can face discrimination when applying for new jobs and this may present an obstacle and disincentive for them to quit (Schuster and Miller [23]). Because of child care and other domestic duties women have higher opportunity cost; therefore, they are less prone to search for a new job (Keith and McWilliams [20], Burgess and Low [26], Ponzo [22]). However, Booth and Francesconi [3] found no large differences in quit rates between genders. In addition, the level of education has a 
positive effect on the propensity of on-the-job search, since high-skilled workers have better labor market alternatives (Theodossiou and Zangelidis [14], Pissarides and Wadsworth [10]). Short tenure has a positive effect on the propensity to quit (Fuentes [2]), as opposed to a high tenure as the latter implies that the current match between the worker and the employer is the best one available in the labour market (Ponzo [22]).

In addition, the number of individuals living in one household effects on-the-job search negatively because the bigger the household is the more costly it is to move in case a new job demands so (Ponzo [22]). According to the empirical literature, job market conditions and employer characteristics have an effect on employee's intention to quit. A high local unemployment rate and a low economic growth will lower the likelihood of employees looking for a new job (Black [21], Pissarides and Wadsworth [10]). A number of studies have shown that the existence of a trade union lower the incentives for on-the-job search (Freeman [30], Miller and Mulvey [27]). Freeman and Medoff [29] argued that trade unions reduce turnover by creating desirable working conditions and by providing discontented workers with a voice alternative to quitting their jobs. Moreover, the ownership structure of the employee has an unequivocal effect on quitting; that is, ceteris paribus, public ownership reduces the intensity of on-the-job search and the number of quits (Bartel and Borjas [1], Ippolito [28]). According to Ponzo [22] public sector employees are at an advantage for various reasons; such as a lower risk of losing their jobs, they experience a lower pressure by managers and supervisors to provide effort on the job, their work environment is calmer and; therefore, they are less likely to start looking for a new job.

\section{Data}

Data was obtained, besides the Hungarian Central Statistical Office-Labor Force Survey (HCSO-LFS), from a database called NetPanel developed by NRC Ltd. The database contains demographic (age, gender, region type, qualification, marital status, size of household) information on 140000 internet users. Members of NetPanel ${ }^{1}$ are committed to occasionally fill out questionnaires on the company's website, which allowed us to obtain the necessary data otherwise not accessible from secondary data source. Only individuals, who were employed at the moment of conducting the survey received the questionnaire, hence the sample did not include the unemployed and the self-employed. The questionnaire was handed out in three waves over the months of October and November, 2011 (2000, 1200 and 1200 people received it respectively), while

\footnotetext{
${ }^{1}$ Subscribing for NetPanel of NRC Ltd. is voluntary; members are incited by sweepstakes to join, but filling out a questionnaire does not necessarily involve a prize. Internet users can receive information about NetPanel through advertisements, which appear in 300 mostly visited Hungarian websites. Visitors of these websites cover the $90 \%$ of the Hungarian population using internet at least once a week.
}

another 1200 people were included in the sample in April, 2012. The sample was weighted and representative for the population aged between 18 and 65 , surfing the web at least once a week, based on attributes as to gender, age group, qualification and region type. In the beginning of the questionnaire, respondents were informed that each question concerns their main job. The dependent variable is job search intensity with the aim to separate as much as possible those who are fully satisfied at their current workplace, and hence, don't even think of looking for a new place, from those who are somewhat unsatisfied with their current employer. A further aspect was to separate within the unsatisfied group those who had only an intention to start searching for a job or have already checked job posts, and perhaps even asked acquaintances for possible options, but have not actually applied yet, from those who have actually applied. Accordingly, from the following three statements respondents had to choose the one that best characterized him or her with regards to the past year or, in case the employment period was shorter, to the period from entering the workplace: "I would like to stay at my current job for as long as possible", "I thought of looking for another job", "I have already applied for another job". The value of the dependent variable could be 1, 2, or 3 respectively. Table 1 shows the descriptive statistics of the data. Those who received a fixed wage were requested to provide the sum of the previous month's net wage, individuals receiving partly or fully commission based wage had to provide the average monthly net wage with respect to the past six months; while employees with a shorter employment period had to calculate the average monthly net wage for the period from entering to the workplace. It must be noted that wages of the April, 2012 wave were discounted to the level of November, 2011. Respondents had to define the amount of the potentially available wage relative to their own-wage according to the following scale: much less $=1$, somewhat less $=2$, approx. the same amount $=3$, somewhat more $=4$, much more $=5$. Thereafter, we refer to this variable as subjective alternative wage. According to the results, $19 \%$ of the subjects couldn't or didn't want to answer these questions. In addition, two binary dependent variables were created in order to examine the effect of job search on alternative wage. If the employee had an opinion about alternative wage the value of the first dependent variable was 1 ; and 0 if the respondent claimed not to know the relative amount of alternative wage in comparison to his or her own wage. The second dependent variable was similarly 1 , if the employee had an opinion on alternative wage; and 0 if he or she didn't know or didn't answer to this question at all. General propensity to respond was measured by a variable that contained the numbers of questions to which the employee did not give any answer. It was assumed that wage cut is a rather rare event, while wage increase is more frequent; therefore, with regard to wage cut we asked whether there was an occasion when the current employer reduced the wage, while with regard to wage increase the most recent time of wage increase had to be provided by the respondent. 
Results showed that $23 \%$ of the respondents had suffered a wage cut at their current job. The relatively high proportion of wage cuts could be attributed to several government measurements. As an aftermath of the tax changes in January, 2011 a significant number of employees could have experienced cuts in net wages, if their employer had not given any wage increase or had not increased their gross wages sufficiently. Sixty one percent of employers who cut respondent's wages are in majority public ownership. Among respondents, who claimed to have experienced wage cuts, there is a big proportion of public employers, which is most likely due to the elimination of the 13th month pay in 2009 . Answers to most recent time of wage increase could be the following: $0=$ never, $1=$ more than 2 years ago, $2=$ one or two years ago, $3=$ within the past 6 to 12 months, $4=$ within the past 6 months. In order to measure wage discrimination respondents had to rate from 1 to 6 the statement "In the same position, with the same tasks, everybody is paid equally", where $1=$ "I totally agree" and $6=$ "I totally disagree". The statement on superior -subordinate relationship was the following: "The relationship among superiors and subordinates is good at my workplace", which had to be rated on a scale of 1 to 6 , as in the case of wage discrimination. Status at workplace was measured through the following categories: $1=$ blue collar worker, $2=$ white collar worker, $3=$ middle management, $4=$ senior management. Moreover, tenure was also measured with a categorical variable according to the following: less than a year $=1,1$ to 4 years $=2,5$ to 9 years $=3,10$ years or longer $=4$. Qualification was measured through 9 categories according to the HCSO-LFS that was merged into the following four categories: 1 = elementary school 8 grades or less, 2 = vocational training, $3=$ secondary education (secondary vocational school, high school, technical school), $4=$ college or university. With the help of dummy variables we measured the presence of trade unions or works council at the employer, and whether the employer was publicly owned by at least $50 \%$ or not. NetPanel provides information on the number of individuals per household, according to which there were 2.94 persons per household on average. Besides the number of individuals per household, we also obtained information on their age and county. The latter was used to insert unemployment rates by county, retrieved from the HCSO-LFS, into the regression equations.

\section{Hypotheses and Econometric Methods}

Regardless of their job search behavior the majority of the respondents $(89 \%)$ have an idea about the prevailing alternative wage. Therefore, in connection to our first research question we articulated the following hypothesis:

\section{H1. On-the-job search does not have a significant effect on the awareness of alternative wage.}

Hypothesis H1 was tested in the multivariate logit model, where awareness of alternative wage was the dependent variable, while independent variables were search intensity, the logarithm of own-wage, company characteristics (such as the owner, the existence of a trade union), individual characteristics (such as position, qualification, age, gender) and the general propensity to respond. As stated in the literature presented in the introduction, calculated alternative wage has a strong positive effect on job search intention and quits. Consequently, it seems plausible that subjective alternative wage has a similar effect; therefore, the next hypothesis related to our second research question is this:

\section{H2. A much higher and somewhat higher subjective alternative wages have a significant and positive effect on search intention and active search.}

Together with alternative wage, the logarithm of own wage as a control variable was also inserted into the model, and based on empirical results we expect it to have a negative effect on search intention and active search. Furthermore, based on the results described in the introduction we could assume a positive effect of wage cut and a negative effect of wage increase on quits. Having the possibility to examine the two events separately, it can be considered useful to assess whether they are both significant, and whether their impact is as it had been expected. On that account, our next hypothesis related to wage cut and wage increase is formulated as below:

\section{H3/A. A former wage cut has a significant and positive effect on the intentions to quit and active search.}

H3/B. A more recent wage increase has a significant and negative effect on the intentions to quit and active search.

To our best knowledge, there has not been a study to reveal direct effect of wage discrimination on the job search behavior of employees. Nevertheless, in accordance with the literature we can assume that wage discrimination significantly reduces job satisfaction; and the lower the level of job satisfaction, the higher the motivation for job search. With this in mind, the following hypothesis was formulated:

\section{H4. The effect of wage discrimination on intentions to quit and active search is positive.}

Hypotheses $\mathrm{H} 2-\mathrm{H} 4$ were tested in a multivariate discrete choice model, where search behavior was the dependent variable. Job search behavior is characterized by search intensity, classified into three categories: (1) respondent has not looked for another job (and has not even thought of doing so); (2) has thought of looking for another job (has search intention); (3) has already been looking for a new workplace since being employed at his or her current workplace (active search). With respect to search intensity, the previously mentioned categories are ranked as below: search intention means a level higher search intensity than not having thought of searching at all; and active search is ranked one level higher than having an intention only. As a dependent variable, job search is ordered, however, considering the fact that the proportional odds assumption is violated based on the Brant test; therefore, ordered-logit model cannot be 
applied. The stereotype logit model represents a solution to this problem, because it does not require the proportional odds assumptions (Anderson [15]). In the case of stereotype logit model, the probability of $\mathrm{s}$ category to occur during observation number $i$ is the following:

$$
\operatorname{Pr}\left(y_{i}=s \mid x_{i 1} \ldots x_{i p}\right)=\frac{\exp \left(\beta_{0 s}+\varphi_{s} \Sigma_{j=1}^{p} x_{i j} \beta_{j}\right)}{\sum_{t=1}^{k} \exp \left(\beta_{0 t}+\varphi_{t} \sum_{j=1}^{p} x_{i j} \beta_{j}\right)}
$$

where $x_{i 1} \ldots x_{i p}$ are the explanatory variables belonging to the observation number $i$, the number of categories of the dependent variables is $k$ (in our case 3 ), $\beta$ are the coefficients of explanatory variables to be estimated, and $\varphi$ are the ranking parameters to be estimated. We inserted wage related variables (the logarithm of net wage, alternative wage, wage cut, the date of the last wage increase, wage discrimination), company characteristics (superior-subordinate relations, public employer, the existence of a trade union), demographic and labor market attributes (gender, age, status, tenure, size of household, qualification, unemployment rate by county) into the regression equation. The unemployment rate is defined at the county level; therefore, the standard errors are corrected for the potential clustering of the residual. The expected direction of wage related variables are shown in $\mathrm{H} 2-\mathrm{H} 4$ hypotheses; while with regards to the expected effect of control variables (company characteristics, demographic and labor market attributes) we can rely on the empirical results mentioned in the introduction.

\section{Estimation Results}

Before examining the factors influencing on-the-job search behavior, we have to understand whether only employees looking for a job are aware of available alternative wages, or whether employees generally have an idea of what the elsewhere potentially accessible wages are. There are two binary dependent variables, each of which took the value of 1 in case the employee was aware of the relative amount of alternative wage in comparison to his or her own wage. The first dependent variable took on the value of 0 , if the employee didn't know the answer, while the second dependent variable did so if the employee didn't know or didn't respond to the question at all. Results of the logit model are shown in Table 2 (model 1 shows results of the first dependent variable; and model 2 reflects the second dependent variable). The search variable is not significant in neither of the models, which allows us to accept our first hypothesis. Among the other explanatory variables tenure, public employer, as well as age for model 1 , had a negative effect on the awareness of alternative wages, while a higher own-wage and vocational qualification affected it positively. However, it should be noted that, to a certain extent, the phrasing of the questions and the method of data collection could have influenced the results. However unlikely it may be, there is a chance that some proportion of non-searchers did not in fact know the alternative wages, and only responded because they were asked to. Certainly, this does not provide a satisfactory explanation for not having ticked "I don't know" instead.

Next in our analysis we looked into factors influencing job search where we applied the stereotype logit regression model mentioned in Section 3. Table 3 shows marginal effects with respect to the last two exit categories, where "search intention" is exit category No. 2 and "active search" is exit category No. 3, while Table 4 represents odds ratios. We performed estimations on the full sample, and also on subsamples by gender; in what follows, if not noted otherwise, the presented estimation results regard the full sample. As we have expected a high own-wage reduces the probability of intention to quit and active search for both genders; however, it had a somewhat stronger impact among men. The relative size of alternative wage in comparison to the own-wage significantly influences intentions to quit and active search. If the alternative wage is much more that means an increase of 13.9 percentage point in the probability of intentions to quit, and an increase of 14.3 percentage point in the probability of active search. A somewhat less or much less alternative wage reduces the probability of intentions to quit and active search to a lesser extent than the extent to which a somewhat more or much more alternative wage increases it. These results hence allow us to accept our second hypothesis according to which alternative wage has a significant effect on intentions to quit and active search.

One important innovation of this study is that it provides separate information on the impact of wage increase and wage cut on job search behavior of employees. We found that if an employee had suffered wage cut previously at his current workplace it increased the probability of both intention to quit and active search (by 6.15 and 3.79 percentage points respectively); however, the impact was stronger among women. With respect to wage increase we have found that it is significant, and when the closer the date of wage increase was to the present, as expected, the less the probability of job search became. In accordance with the above mentioned results we accept the third hypothesis. Here, it should be noted that we don't know the degree of past wage increase and wage cuts.

The variable, which has not been subject of any analysis regarding its direct impact on the employee's job search behavior, is wage discrimination. Employees compare their current wages not only to wages available elsewhere, but also to wages of equally performing colleagues in the same position. The variable is significant and, as expected, the more negative the view on wage discrimination is the more the probability of on-the-job search increases, nevertheless the extent of its impact is surprisingly weak. In accordance to the estimation results we can accept our fourth hypothesis; that is, wage discrimination has a significant and positive effect on intentions to quit and active search.

In what follows we will briefly look into the estimated effects of control variables describing job and firm characteristics. Results show that a one-level-worse superior-subordinate relationship increases the probability of 
intentions to quit by 6.77 percentage point; and of active search by 3.79 percentage point, while we kept all other variables at their means. Promotion could be one of the driving factors of voluntary quits; hence, we supposed that the higher the employee's position the less likely he or she is to look for another workplace. The negative coefficient confirms this; one step higher in the hierarchy decreases the probability of active search by 1.42 percentage point. For women, a higher position has a greater counter-incentive impact on job search. A majority public-owned employer significantly decreases intentions to quit, by more than 5 percentage point, (compared to a not public-owned employer); however, the influence among men is significantly more elevated ( 7.13 percentage points). The negative effect of a publicly owned company on on-the-job search can be the source of several effects. In our opinion, one of the most important features of public employers is the fact that they mostly offer jobs in professions (educator, police officer, firemen, health workers, transport professions) that are rare among private employers, which in itself reduces the number of potential alternative jobs. The special professional experience accumulated at a public employer is often difficult to convert into the knowledge required at most private companies even in fields that are otherwise common for private employers. In accordance with previous researches, the existence of a trade union, or works council at the employer had a significant and negative effect on the probability of job search, but only among men (the probability of active search decreased by 1.8 percentage point).

Finally, we will briefly present the effects of demographic and labor market control variables. It is important to note the role of tenure: an employment period of more than one year but of maximum 4 years increases the probability of active search relative to the reference category ( 1 year, or shorter employment period) by 4.2 percentage point, while an employment period of 5 to 9 years only increases it by 2.37 percentage point. An employment period of 10 years or more did not have any significant effect neither on intentions to quit, nor on active search. Those who started working for their current employer recently or just a couple of years ago have a quite vivid memory of searching for a job, of prevailing alternative wages, and hence, they start easier looking for another job again, if they had realized in the meantime that the current workplace does not perfectly match their expectations. Later, when they have accumulated a greater amount of workplace-specific skills they feel much less motivated to look for a new place, which in most cases, would require them to acquire new professional knowledge. Age has a similar effect as tenure; the beginning of the working-age has a moderate but positive effect on intentions to quit and active search. The age-squared is significantly negative, based on which it seems that older people are less willing to change job. In accordance with previous studies (Fuentes [2], Pissarides and Wadsworth [10]), the effect of qualification is highly significant and positive, which shows that employees with a higher qualification are more likely to look for a new job while being employed. Our analysis shows that one level higher qualification increases the probability of active search by 3.43 percentage point. According to previous explanations (Ponzo [22]), this is due to the fact that more qualified employees are more effective in searching for a job, because of their bigger social network and better relations, and therefore have more employment options. In our view, the higher search activity of employees with a higher qualification can also be attributed to the fact that their skills and professions can be applied in a wider range of fields as opposed to that of low or not qualified employees. A wider selection of job opportunities runs the risk that the employee will have to switch jobs several times in order to find a place that matches his or her competences, interest and wage requirement. In accordance with the literature, gender has a significant effect on job search; a male employee is 1.9 percent more likely to look for a job while being employed. The difficulty of finding a new job greatly depends on the job supply relevant for the employee. Ceteris paribus, an employee will be less likely to look for a new job, if he or she would face difficulties in finding a better job. Differences between regional labor markets are very high in Hungary; therefore, in the regression we included the logarithm of the unemployment rate by county. The results show that the effect of the unemployment rate by county is only significant for women and has a negative effect on the job search behavior. That is, a one percent increase in the county unemployment rate reduces the probability of active job search by 1.58 percentage point. The number of individuals living in one household is only significant for women; an extra habitant decreases the probability of active search by 1 percentage point. One possible explanation for this result is that the more individuals live together the greater the amount of the domestic work becomes, which usually falls on women, and hence, they have less time to search for a job.

\section{Conclusions}

In this study, we examined factors influencing on-the-job search with a special focus on subjective alternative wage, change in wage level and wage discrimination based on a representative sample of Hungarian internet-user employees aged between 18 and 65 . Our estimation results suggest that on-the-job search has no significant impact on the awareness of alternative wages. It seems that regardless of job search behavior employees are aware of the prevailing alternative wages, which have the greatest influence on intention to quit and active search. Our contribution to the literature regarding the effect of changes in wage level is that we have separately measured the effects of wage cut and wage increase, and we found that they are both significant; the former has strong positive effect on intentions to quit and active search, while the latter reduces the probability of on-the-job search. To our best knowledge, this study is the first in revealing a direct effect of wage discrimination on job search behavior 
according to which there is a weak, but positive effect on on-the-job search. The most important conclusion of this study is that in order to retain good employees it is certainly not enough to provide them with a high own wage in comparison to their reservation wage. Employees are sensitive to further wage-related effects, such as alternative wage, change in wage level, and wage discrimination.
Finally, the results of this study confirm the role of non-financial motives in job search. In this respect, superior-subordinate relationships seem to have a special importance. A bad superior-subordinate relationship has a strong positive effect on the job search behavior of employees.

\section{Appendix}

Table 1. Descriptive statistics

\begin{tabular}{|c|c|c|c|c|c|c|}
\hline Variables & Observations & Mean & Variance & Median & Minimum & Maximum \\
\hline Search & 5588 & 1,62 & 0,7 & 1 & 1 & 3 \\
\hline Net own-wage & 4703 & 8 & 87811 & 110000 & 26000 & 2008000 \\
\hline Do not know the alternative wage & 5118 & 0,11 & 0,32 & 0 & 0 & 1 \\
\hline Subjective alternative wage & 4536 & 2,61 & 1,04 & 3 & 1 & 6 \\
\hline Subjective alternative wage is much less & 4536 & 0,18 & 0,38 & 0 & 0 & 1 \\
\hline Subjective alternative wage is somewhat less & 4536 & 0,22 & 0,41 & 0 & 0 & 1 \\
\hline Subjective alternative wage is roughly the same & 4536 & 0,42 & 0,49 & 0 & 0 & 1 \\
\hline Subjective alternative wage is somewhat more & 4536 & 0,13 & 0,34 & 0 & 0 & 1 \\
\hline Subjective alternative wage is much more & 4536 & 0,03 & 0,17 & 0 & 0 & 1 \\
\hline Wage cut & 5596 & 0,23 & 0,42 & 0 & 0 & 1 \\
\hline Date of last wage increase & 5597 & 1,74 & 1,48 & 2 & 0 & 4 \\
\hline Wage discrimination & 5593 & 3,61 & 1,91 & 4 & 1 & 6 \\
\hline Superior-subordinate relationship & 5592 & 3,07 & 1,56 & 3 & 1 & 6 \\
\hline Position & 5590 & 3,26 & 0,68 & 3 & 1 & 4 \\
\hline Union & 5590 & 0,47 & 0,5 & 0 & 0 & 1 \\
\hline State owner & 5586 & 0,35 & 0,48 & 0 & 0 & 1 \\
\hline Tenure & 5589 & 2,62 & 1,07 & 2 & 1 & 4 \\
\hline Tenure: less than 1 year & 5589 & 0,16 & 0,37 & 0 & 0 & 1 \\
\hline Tenure: from 1 to 4 years & 5589 & 0,34 & 0,23 & 0 & 0 & 1 \\
\hline Tenure: from 5 to 9 years & 5589 & 0,2 & 0,4 & 0 & 0 & 1 \\
\hline Tenure: 10 years, or more & 5589 & 0,3 & 0,46 & 0 & 0 & 1 \\
\hline Male & 5600 & 0,55 & 0,5 & 0 & 0 & 1 \\
\hline Age & 5600 & 38,46 & 10,39 & 37 & 18 & 65 \\
\hline Elementary school & 5600 & 0,02 & 0,15 & 0 & 0 & 1 \\
\hline Vocational training & 5600 & 0,24 & 0,43 & 0 & 0 & 1 \\
\hline Secondary school & 5600 & 0,38 & 0,49 & 0 & 0 & 1 \\
\hline College, university & 5600 & 0,36 & 0,48 & 0 & 0 & 1 \\
\hline Size of household & 5600 & 2,94 & 1,26 & 3 & 1 & 6 \\
\hline Unemployment rate by County & 5600 & 0,11 & 0,31 & 0,1 & 0,06 & 0,18 \\
\hline
\end{tabular}


Table 2. Determinants of the awareness of alternative wage. Logit estimates

\begin{tabular}{|c|c|c|c|c|}
\hline & \multicolumn{2}{|c|}{ Model I. } & \multicolumn{2}{|c|}{ Model II. } \\
\hline & Odds ratio & Marginal effects & Odds ratio & Marginal effects \\
\hline \multirow[t]{2}{*}{ Search } & 1.126 & 0.0100 & 1.045 & 0.00568 \\
\hline & $(0.0960)$ & $(0.00721)$ & $(0.0696)$ & $(0.00859)$ \\
\hline \multirow[t]{2}{*}{ Log own-wage } & $2.342 * * *$ & $0.0720 * * *$ & $2.377 * * *$ & $0.112 * * *$ \\
\hline & $(0.352)$ & $(0.0126)$ & $(0.276)$ & $(0.0148)$ \\
\hline \multirow[t]{2}{*}{ State owner } & $0.756^{* *}$ & $-0.0246^{* *}$ & $0.687 * * *$ & $-0.0504 * * *$ \\
\hline & $(0.0947)$ & $(0.0114)$ & $(0.0659)$ & $(0.0134)$ \\
\hline \multirow[t]{2}{*}{ Position } & 1.046432 & 0.991653 & 0.974 & -0.00337 \\
\hline & $(0.155)$ & $(0.0155)$ & $(0.140)$ & $(0.0187)$ \\
\hline \multirow[t]{2}{*}{ Union } & 1.072 & 0.00584 & 1.034 & 0.00426 \\
\hline & $(0.133)$ & $(0.0104)$ & $(0.0996)$ & $(0.0124)$ \\
\hline \multirow[t]{2}{*}{ Vocational training } & $1.761 *$ & $0.0428 * *$ & $1.786^{* *}$ & $0.0678 * *$ \\
\hline & $(0.558)$ & $(0.0216)$ & $(0.445)$ & $(0.0264)$ \\
\hline \multirow[t]{2}{*}{ Secondary } & 1.278 & 0.0203 & $1.514 *$ & $0.0516^{*}$ \\
\hline & $(0.401)$ & $(0.0254)$ & $(0.375)$ & $(0.0299)$ \\
\hline \multirow[t]{2}{*}{ College, university } & 1.006 & 0.000519 & 1.300 & 0.0329 \\
\hline & $(0.331)$ & $(0.0277)$ & $(0.337)$ & $(0.0317)$ \\
\hline \multirow[t]{2}{*}{ Tenure } & $0.872 * *$ & $-0.0116^{* *}$ & $0.821 * * *$ & $-0.0254 * * *$ \\
\hline & $(0.0503)$ & $(0.00485)$ & $(0.0374)$ & $(0.00585)$ \\
\hline \multirow[t]{2}{*}{ Age } & $0.927 *$ & $-0.00641 *$ & 0.963 & -0.00492 \\
\hline & $(0.0398)$ & $(0.00358)$ & $(0.0330)$ & $(0.00440)$ \\
\hline \multirow[t]{2}{*}{ Age-squared } & 1.001 & $4.66 \mathrm{e}-05$ & 1.000 & $9.33 \mathrm{e}-06$ \\
\hline & $(0.000511)$ & $(4.28 \mathrm{e}-05)$ & $(0.000404)$ & $(5.21 \mathrm{e}-05)$ \\
\hline \multirow[t]{2}{*}{ Male } & 1.019 & 0.00155 & 1.085 & 0.0106 \\
\hline & $(0.120)$ & $(0.00996)$ & $(0.0992)$ & $(0.0119)$ \\
\hline \multirow[t]{2}{*}{ Willingness to respond } & 0.979 & -0.00180 & 0.615 & -0.0627 \\
\hline & $(0.412)$ & $(0.0356)$ & $(0.189)$ & $(0.0397)$ \\
\hline \multirow[t]{2}{*}{ Constant } & $0.00340 * * *$ & & $0.000963^{* * *}$ & \\
\hline & $(0.00639)$ & & $(0.00139)$ & \\
\hline Observations & \multicolumn{2}{|c|}{4,292} & \multicolumn{2}{|c|}{4,659} \\
\hline Pseudo R2 & \multicolumn{2}{|c|}{0,0419} & \multicolumn{2}{|c|}{0,0584} \\
\hline
\end{tabular}

Notes: Logit estimates. The second column shows the marginal effects, when all other variables equal their means. For categorical variables (that are not binary), the discrete change can be interpreted for a unit change centered on the mean. Heteroskedasticity robust standard errors are reported in parenthesis. The standard errors are corrected for the potential clustering of the residual at the county level. The symbols $* * *, * *, *$ indicate that coefficients are statistically significant, respectively, at the $1,5,10$ percent level. 
Table 3. Determinants of search behavior. Stereotype logit estimates, marginal effects.

\begin{tabular}{|c|c|c|c|c|c|c|}
\hline & \multicolumn{2}{|c|}{ Whole sample } & \multicolumn{2}{|c|}{ Men } & \multicolumn{2}{|c|}{ Women } \\
\hline & Intention & $\begin{array}{l}\text { Active } \\
\text { search }\end{array}$ & Intention & $\begin{array}{l}\text { Active } \\
\text { search }\end{array}$ & Intention & $\begin{array}{l}\text { Active } \\
\text { search }\end{array}$ \\
\hline \multirow[t]{2}{*}{ County unemployment rate } & $-0.0282 * *$ & $-0.0158 * *$ & -0.0147 & -0.00788 & $-0.0512 * *$ & $-0.0302 * *$ \\
\hline & $(0.0136)$ & $(0.00768)$ & $(0.0205)$ & $(0.0109)$ & $(0.0219)$ & $(0.0140)$ \\
\hline \multirow[t]{2}{*}{ Log own-wage } & $-0.0593 * * *$ & $-0.0332 * * *$ & $-0.0675^{* * *}$ & $-0.0361 * * *$ & $-0.0539 * *$ & $-0.0318 * *$ \\
\hline & $(0.0123)$ & $(0.00808)$ & $(0.0193)$ & $(0.0109)$ & $(0.0241)$ & $(0.0135)$ \\
\hline \multirow[t]{2}{*}{ Alternative wage is much less } & $-0.148 * * *$ & $-0.0676^{* * *}$ & $-0.132 * * *$ & $-0.0578 * * *$ & $-0.170 * * *$ & $-0.0822 * * *$ \\
\hline & $(0.0203)$ & $(0.00685)$ & $(0.0244)$ & $(0.00751)$ & $(0.0275)$ & $(0.0133)$ \\
\hline \multirow[t]{2}{*}{ Alternative wage is somewhat less } & $-0.0792 * * *$ & $-0.0402 * * *$ & $-0.0839 * * *$ & $-0.0399 * * *$ & $-0.0764 * * *$ & $-0.0415 * * *$ \\
\hline & $(0.0184)$ & $(0.00719)$ & $(0.0235)$ & $(0.00880)$ & $(0.0185)$ & $(0.00897)$ \\
\hline \multirow[t]{2}{*}{ Alternative wage is somewhat more } & $0.103 * * *$ & $0.0735^{* * *}$ & $0.0927 * * *$ & $0.0635^{* * *}$ & $0.123 * * *$ & $0.0907 * * *$ \\
\hline & $(0.0139)$ & $(0.0115)$ & $(0.0173)$ & $(0.0174)$ & $(0.0250)$ & $(0.0201)$ \\
\hline \multirow[t]{2}{*}{ Alternative wage is much more } & $0.139 * * *$ & $0.143 * * *$ & $0.137 * * *$ & $0.162 * * *$ & $0.136^{* * *}$ & $0.120^{* * *}$ \\
\hline & $(0.0118)$ & $(0.0268)$ & $(0.0155)$ & $(0.0438)$ & $(0.0207)$ & $(0.0351)$ \\
\hline \multirow[t]{2}{*}{ Wage cut } & $0.0615^{* * *}$ & $0.0379 * * *$ & $0.0549 * * *$ & $0.0320 * * *$ & $0.0727 * * *$ & $0.0474 * * *$ \\
\hline & $(0.00975)$ & $(0.00608)$ & $(0.0161)$ & $(0.00918)$ & $(0.0148)$ & $(0.0129)$ \\
\hline \multirow[t]{2}{*}{ Date of last wage increase } & $-0.0145^{* * *}$ & $-0.00813^{* * *}$ & $-0.0177 * *$ & $-0.00947 * *$ & $-0.00935^{*}$ & $-0.00551^{*}$ \\
\hline & $(0.00511)$ & $(0.00262)$ & $(0.00780)$ & $(0.00402)$ & $(0.00507)$ & $(0.00298)$ \\
\hline \multirow[t]{2}{*}{ Wage discrimination } & $0.0160 * * *$ & $0.00899 * * *$ & $0.0156^{* * *}$ & $0.00836^{* * *}$ & $0.0176 * * *$ & $0.0104 * * *$ \\
\hline & $(0.00329)$ & $(0.00180)$ & $(0.00387)$ & $(0.00193)$ & $(0.00434)$ & $(0.00217)$ \\
\hline \multirow[t]{2}{*}{ Superior-subordinate relationship } & $0.0677 * * *$ & $0.0379 * * *$ & $0.0617 * * *$ & $0.0330 * * *$ & $0.0760 * * *$ & $0.0448 * * *$ \\
\hline & $(0.00485)$ & $(0.00328)$ & $(0.00421)$ & $(0.00304)$ & $(0.00849)$ & $(0.00570)$ \\
\hline \multirow[t]{2}{*}{ Position } & $0.0253^{* * *}$ & $0.0142 * * *$ & $0.0216^{* *}$ & $0.0115 * *$ & $0.0324 * * *$ & $0.0191 * * *$ \\
\hline & $(0.00862)$ & $(0.00470)$ & $(0.0105)$ & $(0.00559)$ & $(0.0118)$ & $(0.00741)$ \\
\hline \multirow[t]{2}{*}{ State owner } & $-0.0561 * * *$ & $-0.0300 * * *$ & $-0.0713 * * *$ & $-0.0352 * * *$ & -0.0344 & $-0.0199 *$ \\
\hline & $(0.0197)$ & $(0.00939)$ & $(0.0259)$ & $(0.0114)$ & $(0.0212)$ & $(0.0112)$ \\
\hline \multirow[t]{2}{*}{ Union } & $-0.0317 * *$ & $-0.0177 * *$ & $-0.0353 *$ & $-0.0188^{*}$ & -0.0289 & -0.0169 \\
\hline & $(0.0124)$ & $(0.00688)$ & $(0.0185)$ & $(0.00964)$ & $(0.0248)$ & $(0.0150)$ \\
\hline \multirow[t]{2}{*}{ Tenure: from 1 to 4 years } & $0.0713 * * *$ & $0.0420 * * *$ & $0.0818^{* *}$ & $0.0477 * *$ & $0.0582 * * *$ & $0.0351 * * *$ \\
\hline & $(0.0171)$ & $(0.0117)$ & $(0.0342)$ & $(0.0214)$ & $(0.0221)$ & $(0.0129)$ \\
\hline \multirow[t]{2}{*}{ Tenure: from 5 to 9 years } & $0.0396^{* *}$ & $0.0237^{*}$ & $0.0614^{* *}$ & $0.0370 * *$ & 0.0101 & 0.00605 \\
\hline & $(0.0190)$ & $(0.0126)$ & $(0.0287)$ & $(0.0188)$ & $(0.0311)$ & $(0.0192)$ \\
\hline \multirow[t]{2}{*}{ Tenure: 10 years or more } & -0.0293 & -0.0158 & -0.0240 & -0.0124 & -0.0264 & -0.0151 \\
\hline & $(0.0206)$ & $(0.0114)$ & $(0.0315)$ & $(0.0162)$ & $(0.0337)$ & $(0.0194)$ \\
\hline \multirow[t]{2}{*}{ Male } & $0.0350 * * *$ & $0.0193 * * *$ & & & & \\
\hline & $(0.0123)$ & $(0.00636)$ & & & & \\
\hline \multirow[t]{2}{*}{ Age } & $0.0160 * * *$ & $0.00894 * * *$ & $0.0200 * * *$ & $0.0107 * * *$ & 0.0129 & 0.00763 \\
\hline & $(0.00396)$ & $(0.00227)$ & $(0.00503)$ & $(0.00290)$ & $(0.00950)$ & $(0.00565)$ \\
\hline \multirow[t]{2}{*}{ Age-sqared } & $-0.000253 * * *$ & $-0.000142 * * *$ & $-0.000299 * * *$ & $-0.000160 * * *$ & $-0.000224^{*}$ & $-0.000132 *$ \\
\hline & $(4.92 \mathrm{e}-05)$ & $(2.78 \mathrm{e}-05)$ & $(6.59 \mathrm{e}-05)$ & $(3.78 \mathrm{e}-05)$ & $(0.000122)$ & $(7.33 e-05)$ \\
\hline \multirow[t]{2}{*}{ Education } & $0.0612 * * *$ & $0.0343^{* * *}$ & $0.0687 * * *$ & $0.0367 * * *$ & $0.0499 * * *$ & $0.0294 * * *$ \\
\hline & $(0.00832)$ & $(0.00595)$ & $(0.00875)$ & $(0.00532)$ & $(0.0160)$ & $(0.0103)$ \\
\hline Household size & $-0.00992 *$ & $-0.00556^{*}$ & -0.00539 & -0.00288 & $-0.0182 * *$ & $-0.0107 * *$ \\
\hline & $(0.00556)$ & $(0.00324)$ & $(0.00808)$ & $(0.00439)$ & $(0.00819)$ & $(0.00427)$ \\
\hline Observations: & 3,8 & 08 & 2,1 & 02 & 1,7 & 06 \\
\hline Log pseudolikelihood & -329 & 7,09 & -191 & 0,58 & -137 & 72,7 \\
\hline
\end{tabular}

Notes: Stereotype logit estimates. The coefficients represent the marginal effects, when all other variables equal their means. For categorical variables (that are not binary), the discrete change can be interpreted for a unit change centered on the mean. Heteroskedasticity robust standard errors are reported in parenthesis. The standard errors are corrected for the potential clustering of the residual at the county level. The symbols ***, **, * indicate that coefficients are statistically significant, respectively, at the 1, 5, 10 percent level. Sample weights are used. 
Table 4. Determinants of search behavior. Stereotype logit estimates, odds ratios

\begin{tabular}{|c|c|c|c|}
\hline & Whole sample & Men & Women \\
\hline & Odds ratio & Odds ratio & Odds ratio \\
\hline \multirow[t]{2}{*}{ County unemployment rate } & $0.789^{* *}$ & 0.878 & $0.664^{* *}$ \\
\hline & $(0.0910)$ & $(0.159)$ & $(0.124)$ \\
\hline \multirow[t]{2}{*}{ Log own-wage } & $0.607 * * *$ & $0.553 * * *$ & $0.650^{* *}$ \\
\hline & $(0.0667)$ & $(0.106)$ & $(0.123)$ \\
\hline \multirow[t]{2}{*}{ Alternative wage is much less } & $0.304 * * *$ & $0.332 * * *$ & $0.265^{* * *}$ \\
\hline & $(0.0504)$ & $(0.0667)$ & $(0.0620)$ \\
\hline \multirow[t]{2}{*}{ Alternative wage is somewhat less } & $0.523 * * *$ & $0.491 * * *$ & $0.551 * * *$ \\
\hline & $(0.0737)$ & $(0.0878)$ & $(0.0800)$ \\
\hline \multirow[t]{2}{*}{ Alternative wage is somewhat more } & $2.696^{* * *}$ & $2.520 * * *$ & $3.083^{* * *}$ \\
\hline & $(0.362)$ & $(0.527)$ & $(0.800)$ \\
\hline \multirow[t]{2}{*}{ Alternative wage is much more } & $5.758 * * *$ & $7.457 * * *$ & $4.175^{* * *}$ \\
\hline & $(1.675)$ & $(3.545)$ & $(1.597)$ \\
\hline \multirow[t]{2}{*}{ Wage cut } & $1.720 * * *$ & $1.652 * * *$ & $1.845^{* * *}$ \\
\hline & $(0.146)$ & $(0.230)$ & $(0.252)$ \\
\hline \multirow[t]{2}{*}{ Date of last wage increase } & $0.885 * * *$ & $0.856^{* *}$ & $0.928 *$ \\
\hline & $(0.0357)$ & $(0.0527)$ & $(0.0377)$ \\
\hline \multirow[t]{2}{*}{ Wage discrimination } & $1.145^{* * *}$ & $1.147 * * *$ & $1.151 * * *$ \\
\hline & $(0.0323)$ & $(0.0421)$ & $(0.0366)$ \\
\hline \multirow[t]{2}{*}{ Superior-subordinate relationship } & $1.769 * * *$ & $1.720 * * *$ & $1.835 * * *$ \\
\hline & $(0.0698)$ & $(0.0771)$ & $(0.110)$ \\
\hline \multirow[t]{2}{*}{ Position } & $1.238 * * *$ & $1.209 * *$ & $1.295^{* * *}$ \\
\hline & $(0.0904)$ & $(0.110)$ & $(0.123)$ \\
\hline \multirow[t]{2}{*}{ State owner } & $0.628 * * *$ & $0.543 * * *$ & $0.761^{*}$ \\
\hline & $(0.0973)$ & $(0.105)$ & $(0.126)$ \\
\hline \multirow[t]{2}{*}{ Union } & $0.766 * * *$ & $0.734 *$ & 0.795 \\
\hline & $(0.0785)$ & $(0.121)$ & $(0.157)$ \\
\hline \multirow[t]{2}{*}{ Tenure: from 1 to 4 years } & $1.852 * * *$ & $2.117 * *$ & $1.601 * * *$ \\
\hline & $(0.281)$ & $(0.668)$ & $(0.281)$ \\
\hline \multirow[t]{2}{*}{ Tenure: from 5 to 9 years } & $1.411 * *$ & $1.769 * *$ & 1.085 \\
\hline & $(0.238)$ & $(0.469)$ & $(0.273)$ \\
\hline \multirow[t]{2}{*}{ Tenure: 10 years or more } & 0.784 & 0.812 & 0.812 \\
\hline & $(0.136)$ & $(0.227)$ & $(0.216)$ \\
\hline \multirow[t]{2}{*}{ Male } & $1.341 * * *$ & & \\
\hline & $(0.138)$ & & \\
\hline \multirow[t]{2}{*}{ Age } & $1.144 * * *$ & $1.192 * * *$ & 1.109 \\
\hline & $(0.0364)$ & $(0.0573)$ & $(0.0835)$ \\
\hline \multirow[t]{2}{*}{ Age-sqared } & $0.998 * * *$ & $0.997 * * *$ & $0.998^{*}$ \\
\hline & $(0.000389)$ & $(0.000633)$ & $(0.000962)$ \\
\hline \multirow[t]{2}{*}{ Education } & $1.676 * * *$ & $1.829 * * *$ & $1.490 * * *$ \\
\hline & $(0.121)$ & $(0.156)$ & $(0.198)$ \\
\hline \multirow[t]{2}{*}{ Household size } & $0.920^{*}$ & 0.954 & $0.865^{* *}$ \\
\hline & $(0.0437)$ & $(0.0680)$ & $(0.0544)$ \\
\hline Observations: & 3,808 & 2,102 & 1,706 \\
\hline Log pseudolikelihood & $-3297,09$ & $-1910,58$ & $-1372,7$ \\
\hline
\end{tabular}

Notes: Stereotype logit estimates. Heteroskedasticity robust standard errors are reported in parenthesis. The standard erros are corrected for the potential clustering of the residual at the county level. The symbols $* * *, * * *$ indicate that coefficients are statistically significant, respectively, at the 1, 5, 10 percent level. Sample weights are used. 


\section{Acknowledgements}

I would like to thank János Köllö, György Molnár, István R. Gábor for useful comments and suggestions. All remaining errors are my own responsibility.

\section{REFERENCES}

[1] A. Bartel and G. Borjas. Wage Growth and Job Turnover: An Empirical Analysis. In: Studies in Labor Markets, edited by Sherwin Rosen, 65-90. University of Chicago Press, 1981

[2] A. Fuentes. The Determinants of the On-the-Job Search: An Empirical Exploration, IMF Working Paper, WP/02/156, 2002

[3] A. L. Booth and M. Francesconi. Job mobility in 1990s Britain: Does gender matter? In: Research in Labor Economics, Vol. 19, 173-189, 2000

[4] A. Souza-Poza, F. Henneberger. Analyzing Job Mobility with Job Turnover Intentions: An International Comparative Study, Journal of Economic Issues, Vol. 38, No. 1, 113-137, 2004

[5] A. E. Clark. What really matters in a job? Hedonic measurement using quit data. Labour Economics, Vol. 8, 223-242, 2001

[6] A. E. Clark, Y. Georgellis, and P. Sanfey. Job satisfaction, wage changes and quits: Evidence from Germany, Research in Labor Economics, Vol. 17, 95-121, 1998

[7] C. B. Jesper, R. Lentz, D. T. Mortensen, G. R. Neumann, A. Werwatz. On-the-Job Search and the Wage Distribution, Journal of Labor Economics, Vol. 23(1), 31-58, 2005

[8] C. M. Campbell III and K. S. Kamlani, The Reasons for Wage Rigidity: Evidence From a Survey of Firms, The Quarterly Journal of Economics, Vol. 112, No. 3, 759-789, 1997

[9] C. Martin. Labor Turnover: Evidence from UK Establishment. Brunel University, Economics and Finance Discussion Papers, 1998

[10] C. A. Pissarides and J. Wadsworth. On-the-job search: some empirical evidence from Britain, European Economic Review, 38(2), 385-402, 1994

[11] E. Barth and H. Dale-Olsen. Monopsonistic discrimination, worker turnover, and the gender wage gap, Labour Economics, Vol.16, 589-597, 2009

[12] E. L. Groshen. The Structure of the Female/Male Wage Differential: Is It Who You Are, What You Do, or Where You Work?, The Journal of Human Resources, Vol. 26, No. 3, 457-472, 1991

[13] G. A. Akerlof, W.T. Dickens and G. L. Perry. The Macroeconomics of Low Inflation. Brookings Papers on Economic Activity, No. 1., 7-8, 1996

[14] I. Theodossiou and A. Zangelidis. Should I Stay or Should I go? The effect of gender, education and unemployment on labour market transitions, Labour Economics, Vol. 16(5), 566-577, 2009

[15] J. A. Anderson. Regression and ordered categorical variables.
Journal of the Royal Statistical Society, Series B., 46(1):1-30, 1984

[16] J. Delfgaauw. The effect of job satisfaction on job search: Not just whether, but also where, Labour Economics, Vol. 14, 299-317, 2007

[17] J. Pfeffer and N. Langton. The Effect of Wage Dispersion on Satisfaction, Productivity, and Working Collaboratively: Evidence from College and University Faculty. Administrative Science Quarterly, Vol. 38, No. 3, 382-407, 1993

[18] J. Shorey. An Analysis Of Quits using Industry Turnover Data. The Economic Journal, Vol. 90, No. 360, 821-837, 1980

[19] K. Burdett. A theory of employee job search and quit rates. American Economic Review, Vol. 68, no. 1, 212-220, 1978

[20] K. Keith and A. McWilliams. The Returns to Mobility and Job Search by Gender, Industrial and Labor Relations Review, Vol. 52, No. 3, 460-477,1999

[21] M. Black. An Empirical Test of the Theory of On-The-Job Search, The Journal of Human Resources, Vol. 16, 129-140, 1981

[22] M. Ponzo. On-the-job search in Italian Labour Market: An Empirical Analysis. International Journal of Economics and Business, Vol. 19(2), 213-232, 2012

[23] M. Schuster and C. S. Miller. An Empirical Assessment of the Age Discrimination in Employment Act. Industrial and Labor Relations Review, Vol. 38, No. 1, 64-74, 1984

[24] M. A. Shields and S. W. Price. Racial harassments, job satisfaction and intentions to quit: evidence from the British nursing profession. Economica, Vol. 69, 295-326., 2002

[25] N. Kristensen and N. Westergard-Nielsen. Does Low Job Satisfaction Lead to Job Mobility?, IZA Discussion Paper No. 1026, 2004

[26] P. Burgess, S. Low. Pre-unemployment Job Search and Advance Job Loss Notice, Journal of Labor Economics, Vol. 10, No. 3, 258-86., 1992

[27] P. Miller, C. Mulvey. Australian Evidence on the Exit/Voice Model of the Labor Market. Industrial and Labor Relations Review, Vol. 45, No 1, 44-57, 1991

[28] R. A. Ippolito. Why Federal Workers Don't Quit. The Journal of Human Resources, Vol. 22, No. 2, 281-299, 1987

[29] R. B. Freeman and J. L. Medoff. What do unions do? New York: Basic Books, 1984.

[30] R. B. Freeman. The Exit-Voice Tradeoff in the Labor Market: Unionism, Job Tenure, Quits, and Separations, The Quarterly Journal of Economics, Vol. 94, No. 4, 643-673, 1980

[31] T. F. Bewley. Why Wages Don't Fall During a Recession, Harvard University Press, pp. 170-198, 1999

[32] W. G. Johnson and J. Lambrinos. Wage Discrimination against Handicapped Men and Women, The Journal of Human Resources Vol. 20, No. 2, 264-277, 1985 